\title{
The game: Predatory journal vs. SCOPUS
}

\author{
Dalowar Hossan \\ dalowarhossan.bd@gmail.com
}

\begin{abstract}
The aim of this study is to identify the features of fraudulent journals. Fraudulent journals wasted valuable manuscripts when scholars and authors publish their works in this kind of journal. Fraud journals publish the articles without reviewing the process with a high rate of fee. Purposive sampling technique and document analysis method have been used to conduct this research. One Scopus indexed journal has been selected for reviewing their articles and investigating the publication process. Based on the discussion of this study, the researcher found some characteristics of predatory/fraud/ journals that will help the scholars to avoid publishing fake journals.
\end{abstract}

Keywords: Predatory journal, Turkish Journal of Computer and Mathematics Education, Scopus

\section{INTRODUCTION}

The business model of so-called "predatory" scientific publications is based on a paying openaccess (OA) publishing model, in which the publisher does not charge a subscription fee but instead accepts payment directly from the authors for the publication of the paper. As a result, everyone can browse the content for free. However, the predatory approach involves a conflict of interest that has the potential to threaten academic publishing's reputation.

Predatory journals employ many strategies and techniques to prove themselves respectable and draw the interest of young naive researchers or who would like to publish too quickly to achieve promotion (Duc, Thong \& Masic, 2020; Duc, Khoa \& Thong, 2020; Duc et al., 2020). The main aim of Predators is to make money from author payments. The worst of them falsify peer reviews and print anything for money (Hossan, 2020). This practice of enticing prey researchers to publish valid work in fake journals not only causes tremendous loss of funds and precious resources but also causes the loss of significant validated study that may have been a breakthrough in research progress (Masic, 2020; 2017; 2016).

One of the most serious challenges to science nowadays is the appearance of bogus scientific publications (Masic, 2017; Beall, 2016). Fake journals have harmed many scientists, particularly in developing countries. Not only can such false articles protect themselves from being classified as bogus articles, but they also protect themselves from official indexing or registration by different reputable organizations (for example, Scopus) or regulatory agencies, which may result in a scientific disaster (List of Misleading and Fake Metrics, 2020). A community of people, such as editors and dealers, can be able to effectively manage the bulk of fake publications. Those publications send invites to all writers through different forms of social media, such as Facebook, Twitter, What's app, and other similar platforms. To attract authors, 
predatory journal dealers sometimes organize different types of webinars.

Therefore, this study is going to investigate the characteristics of predatory journals.

\section{LITERATURE REVIEW}

Macháek and Srholec (2019) detailed that the tendency to publish in predatory publications is linked to the country's science evaluation quality. In countries where a tradition of appraisal forces scholars to publish in reputable journals, there is little or no incentive to publish in predatory journals. Publication in a dubious predatory journal will hurt rather than help a researcher's credibility.

According to Simón (2016), the bulk of papers published in predatory journals originated in Third World countries such as Turkey, Jordan, Malaysia, Pakistan, and, in particular, Nigeria. In 2018, Selcuk quantitatively reported that researchers from India, Nigeria, and Turkey had the largest number of publications in predatory journals, examining 24,840 papers published in 832 stand-alone journals mentioned in Beall's list (2019). Asia countries were consistently singled out in related surveys (Demir, 2018; Shen \& Bjork, 2015).

Further research into the demographics of writers revealed that those who published in predatory journals were young and novice authors (Xia et al., 2015; Frandsen, 2017). Many of these writers have little to no familiarity with scholarly writing, and most of them want to maximize their number of publications (Xia et al., 2015), so they select journals that "pay high and publish quickly" (Truth, 2012). Aside from that, promotion schemes, reward allowance systems, "publish-or-perish" coercion, unawareness, and policymakers' attitudes are all possible explanations for writers to publish in predatory journals (Simón, 2016; Shuva \& Taisir, 2016).

China overtook the United States as the world's leading producer of science journals in 2016 (Nature Index 2018). Ph.D. students made significant contributions to this advancement. According to a survey from the PRC Ministry of Education, there were 362,000 Ph.D. students in 2017, with the figure expected to rise in the next two years. Often Ph.D. candidates are full-time researchers with no financial support, and they must write a certain number of articles in a certain amount of time to be eligible for degrees. As a result, Ph.D. students in China are under a lot of pressure to write articles. As a result of the huge growth in open access journals in China, which has increased from 685 (Hu et al., 2012) in 2012 to over 1200 by 2017, the number of "dishonorable" publications has increased as well (Xia, 2018).

At least two major organizations, Times Higher Education and QS, rely heavily on data from Scopus in publishing their annual rankings of universities worldwide. With more citations of its academics' works in Scopus, a university stands a greater chance of boosting its global rankings. While many of these authors come from countries with large populations such as India, Indonesia, the Philippines and Egypt, Malaysia's listing among the top countries of origin may reflect badly on the quality of local academic work. At the top of the list is Kazakhstan with $17 \%$ of such articles, followed by Indonesia (16.73\%), Iraq (13\%), Albania (12\%) and Malaysia (11.6\%) according to Scopus (2018).

\section{OBJECTIVE}

(1) To identify the characteristics of fraudulent/ predatory journals.

\section{METHODOLOGY}


Purposive sampling technique and document analysis method had been used to select the sample for this study. The experience of the previous study (PREDATORY JOURNALS ARE INDEXING IN REPUTED DATABASES: A CASE STUDY OF UNSOLVED ISSUES) had been motivated the researcher to conduct the study. One Scopus indexed journal named Turkish

Journal of Computer and Mathematics Education was selected. The study period was 20 March 2021 to 22 April 2021. The researcher read the articles of the journal carefully to reveal the reality. As the journal is indexed in Scopus, therefore researcher sent mail to the content service desk for confirmation about the Scopus status of the journal. The researcher sent two articles to the journal to investigate the publication process.

\section{BACKGROUND OF THE JOURNAL}

\section{Turkish Journal of Computer and Mathematics Education (e-ISSN 1309-4653)}

Turkish Journal of Computer and Mathematics Education (TURCOMAT) is an international refereed (peer-reviewed) journal and published three issues per year (April, August and December) by TURKBILMAT Education Services. The Journal publishes educational researches related to mathematics education. The journal is devoted to action researcher mathematics teachers, teacher educators, researchers, computer education and mathematics teacher candidates, foundations and people who are interested in mathematics education.

Recently the journal is using two domains (1) https://dergipark.org.tr/en/pub/turkbilmat (2) https://turcomat.org/index.php/turkbilmat (registered in 2020-12-25). Scopus authentication link: https://www.scopus.com/sourceid/21100902608 and http://dergipark.gov.tr/turkbilmat is the listed domain to Scopus for this journal which is different from the usage domains. Image 1 confirmed the journal is under Scopus indexed.

\section{Gmail Galowar Hossan <dalowarhossan.bd@gmail.com>

\begin{tabular}{|c|c|}
\hline $\begin{array}{l}\text { Scopus Support (ELS) <ScopusSupport@elsevier.com> } \\
\text { Reply-To: "Scopus Support (ELS)" <ScopusSupport@elsevier.com> } \\
\text { To: dalowarhossan.bd@gmail.com }\end{array}$ & Wed, Mar 24, 2021 at 1:41 PM \\
\hline
\end{tabular}

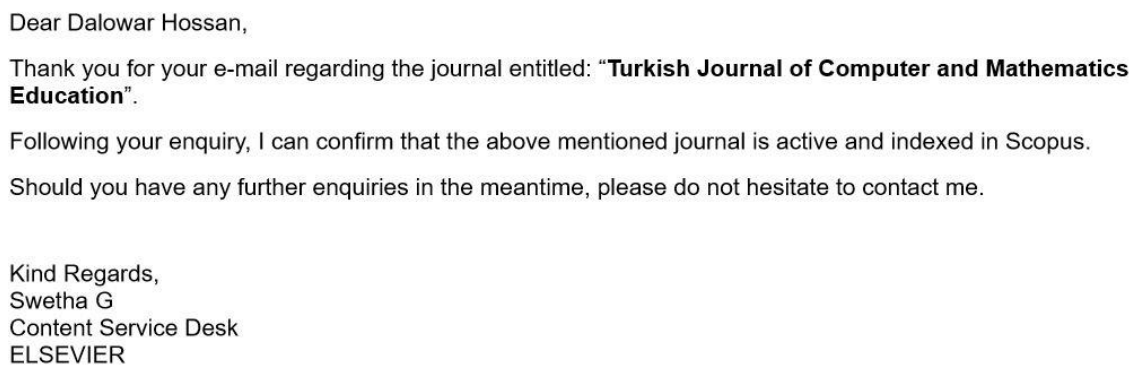

Image 1. Confirmation mail from Scopus authority

\section{Journal's aim}

Turkish Journal of Computer and Mathematics Education (TURCOMAT) was founded as an international journal from the reflection of information technology (IT) especially for mathematics education idea. We are intended to combine computers and mathematics as 
"information technology for mathematics education" in this journal because of the fact that a recent indication of the increasing range of work for researchers and educators comes from two

sources; computers and mathematics education. We are fortunate that technology provides us with windows to look at education from new ways.

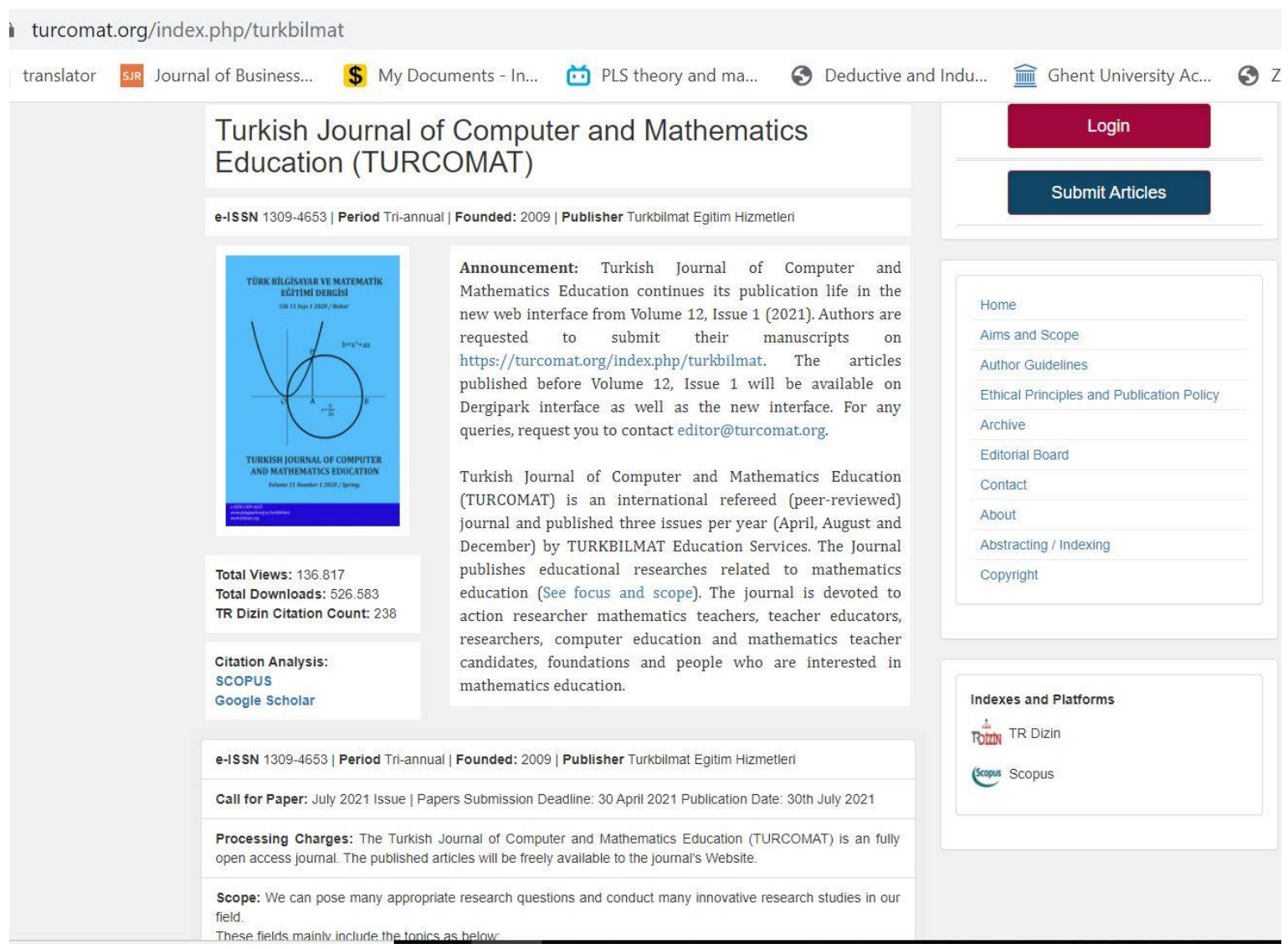

Image 2. New interface of Turkish Journal of Computer and Mathematics Education 


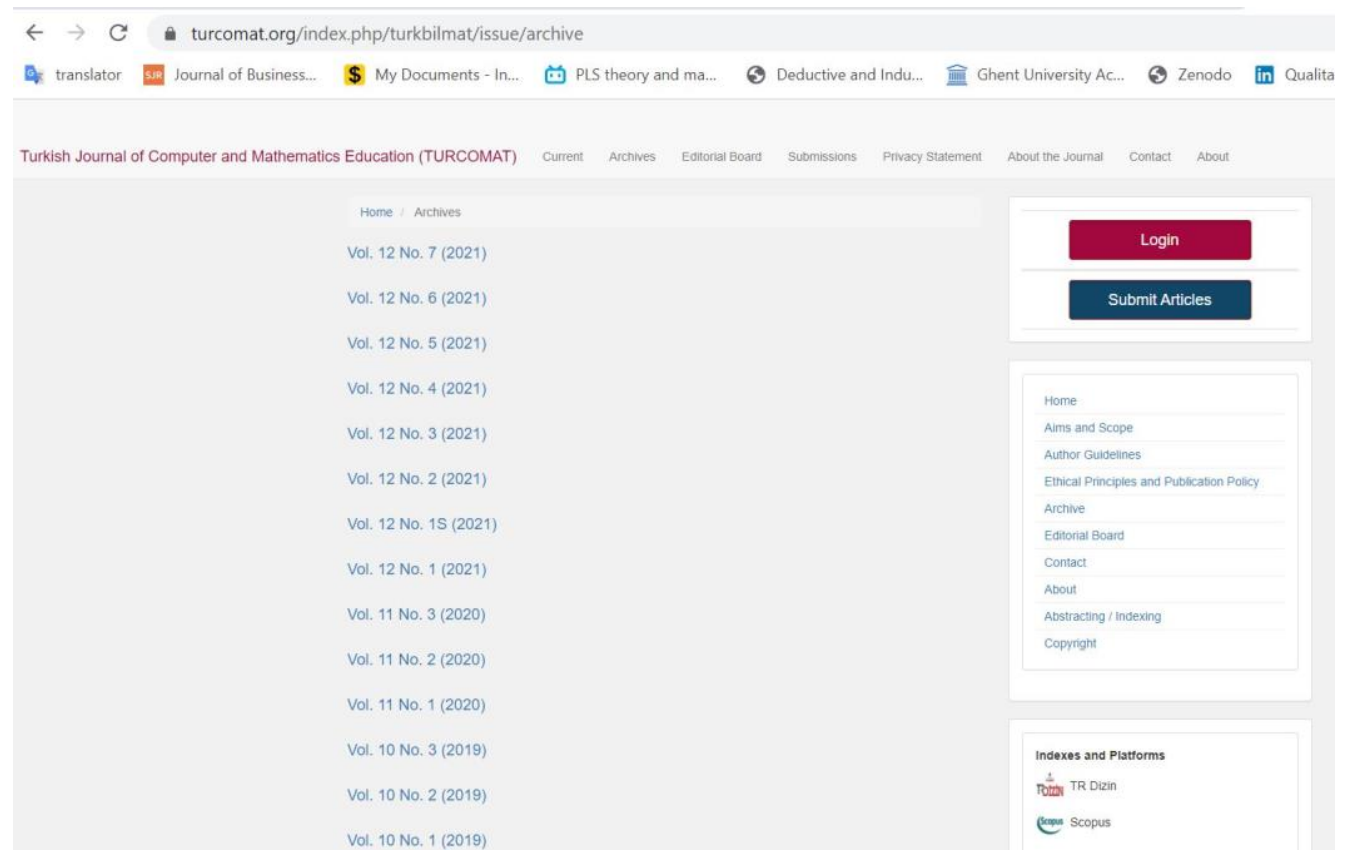

Image 3. Archives of New interface of Turkish Journal of Computer and Mathematics Education

을 dergipark.org.tr/en/pub/turkbilmat

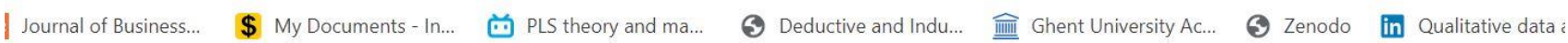

\section{Turkish Journal of Computer and Mathematics Education (TURCOMAT)}

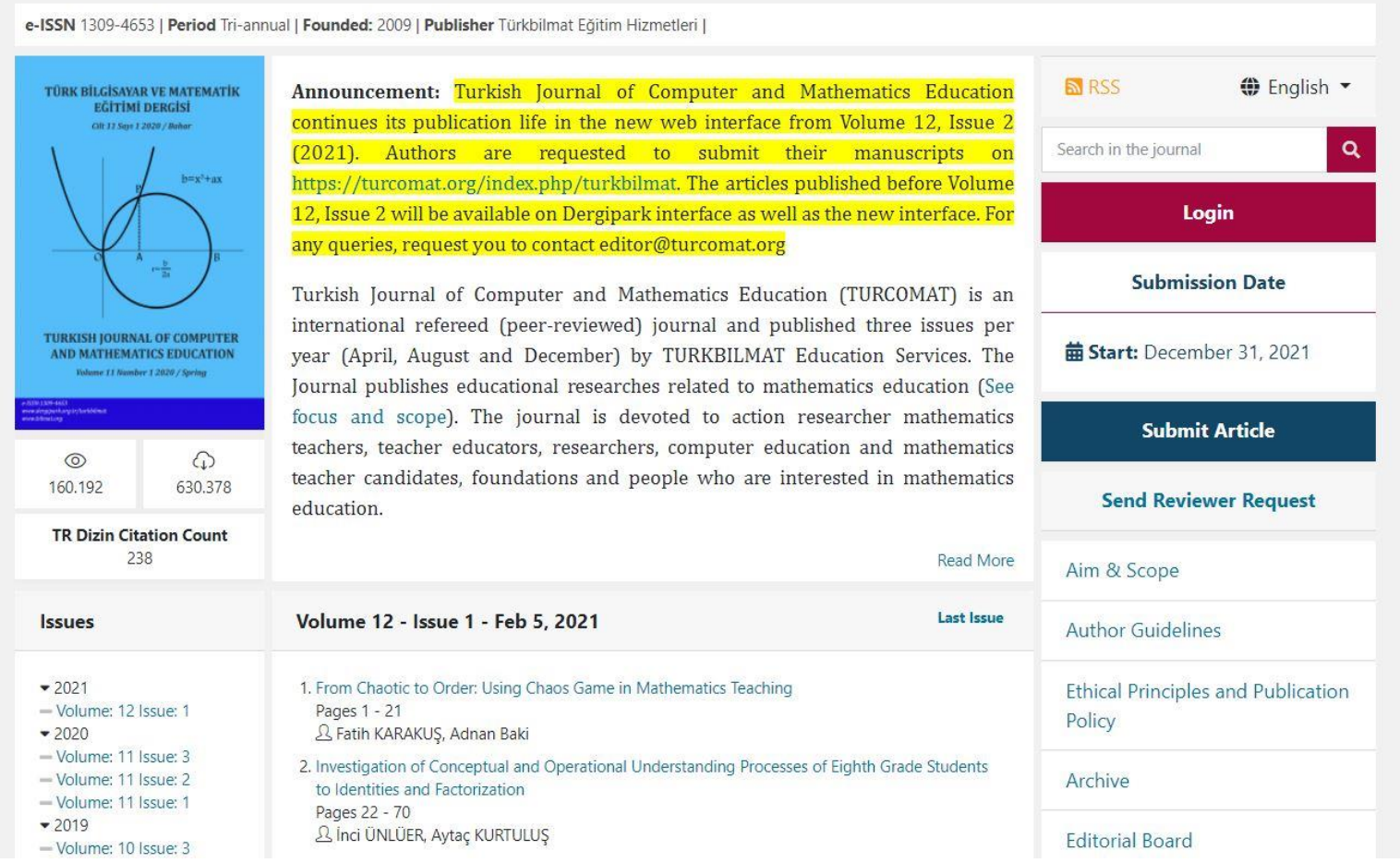

Image 4. Old interface of Turkish Journal of Computer and Mathematics Education

\section{Scope of the journal}

These fields mainly include the topics as below: 
- training in-service mathematics teachers on IT through in-service courses,

- training pre-service mathematics teachers on IT through undergraduate programs,

- understanding how students learn mathematics and solve problems,

- identifying what student learn and think in mathematics,

- assessing and evaluating mathematics curriculum,

- designing and producing distance learning tools for teachers and students.

\section{ARTICLE REVIEW}

Article 1: A Malaysian Empirical Study of the Associations among Transformational Leadership, Transactional Leadership, Organizational Culture and Succession Planning The authors are unable to reach the research objective 1 in their article. They did not identify the level of transformational leadership, transactional leadership style, organizational culture.

A Malaysian Empirical Study of the Associations among Transformational Leadership, Transactional Leadership, Organizational Culture and Succession Planning

Vichetera Rajagani @ Diwyaa ${ }^{1 *}$, Mahaliza Mansor²

${ }_{1 * 2}, 2$ Department of Educational Management, Faculty of Management and Economics,

Universiti Pendidikan Sultan Idris, 35900, Tanjong Malim, Perak, Malaysia

diyaphd@yahoo.com ${ }^{1 *}$

Article History: Received: 10 November 2020; Revised: 12 January 2021; Accepted: 27 January 2021;

Published online: 05 April 2021

Abstract: This study aimed to identify the relationship between transformational leadership, transactional leadership and organizational culture factors withsuccession planning. Besides that, this paper also intended to look at the influence and contribution of those factors on succession planning implementation. The sample of this study is focused on the Education Service Officers at Ministry of Education (MoE), Malaysia. Data were collected from 261 Education Officers from 21 Division in Ministry of Education. Malaysia. The findings revealed that transformational leadership, transactional leadership and organizational culture have positive significant relationship with succession planning. Besides that, this study also found that transformational leadership style, transactional leadership style and organizational culture contributing to the implementation of succession planning. Therefore, according to the research findings, we recommend that transformational and transactional leadership style, besides organizational culture factors should be considered in implementing succession planning.

Keywords: Succession Planning, Transformational Leadership, Transactional Leadership, Organizational Culture, Human Resource Management

Image 5. A Malaysian Empirical Study of the Associations among Transformational Leadership, Transactional Leadership, Organizational Culture and Succession Planning 


\section{Research Objectives}

1 To identify the level of transformational leadership, transactional leadership style, organizational culture and succession planning.

2 To identify the relationship between transformational leadership, transactional leadership style, organizational culture with succession planning.

3 To identify the influence transformational leadership, transactional leadership style, organizational culture on succession planning.

\section{Research Framework}

Figure 1 shows research framework of this study. This study is based on Rothwell (2005) Theory, followed by Transformational and Transactional Leadership. Theory by Bass \& Avolio (2004) and supported by Competing Value Framework of Organizational Culture by Cameron \& Quinn (2005). This study consists of three independent variable which is transformational leadership, transactional leadership and organizational culture and one dependent variable which is succession planning. This study explored the relationship between the three mentioned independent variable with the dependent variable as per showed in figure 1 .

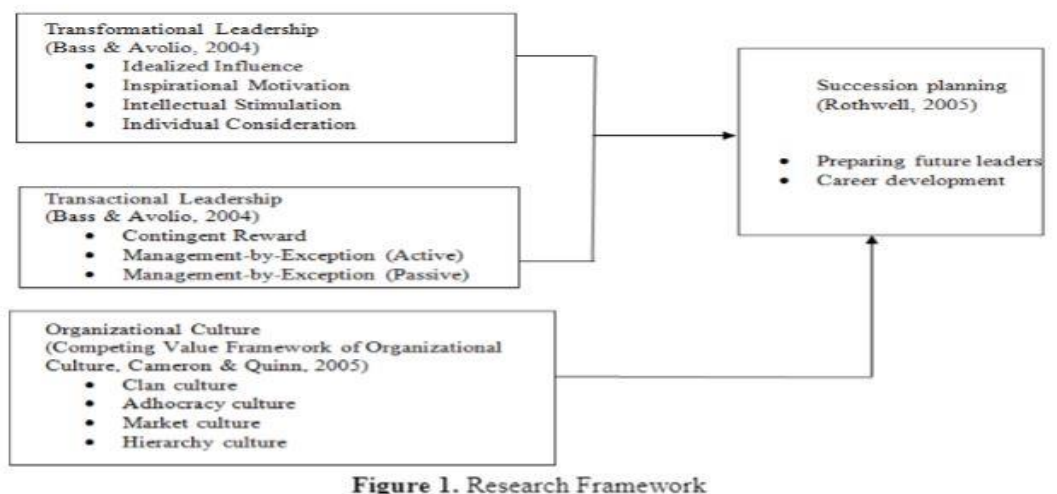

Image 6. A Malaysian Empirical Study of the Associations among Transformational Leadership, Transactional Leadership, Organizational Culture and Succession Planning

Article 2: The Effect of Empathy on Students' Motivation in Social Entrepreneurship among Undergraduates

The total in-text citation in this article is 31 but it is 67 in the reference list.

\section{The Effect of Empathy on Students' Motivation in Social Entrepreneurship among Undergraduates}

\section{Norsamsinar Samsudin ${ }^{a^{*}}$, Ahmad Zainal Abidin Abd Razak ${ }^{b}$, Juliana Osman ${ }^{c}$, Thuraiya Zakaria ${ }^{d}$, Nazrina Aziz}

$\mathrm{a}^{*}, b, c, d$ Faculty of Management and Economics, Universiti Pendidikan Sultan Idris, Malaysia

'School of Quantitative Sciences, Universiti Utara Malaysia

Correspondence Author: norsamsinar@fpe.upsi.edu.my ${ }^{a^{*}}$

Article History: Received: 11 August 2020; Accepted: 27 October 2020; Published online: 23 December 2020 Abstract: This study aimed to investigate the effect of empathy on students motivation in social entrepreneurship among undergraduates. A total of 300 students from 15 selected public universities in Malaysia under the Entrepreneurial Act Us Program (Enactus) were involved in this research. A set of questionnaireswas utilized to collect thedata. Descriptive statistics such as mean and standard deviation were used to identify the level of students' motivation towards social entrepreneurship and empathy. Inferential statistics including correlation and simple linear regression were used to test the research hypotheses of the research. The results show that there is a significant effect between empathy and students' motivation for social entrepreneurship.

Image 7. The Effect of Empathy on Students' Motivation in Social Entrepreneurship among Undergraduates 


\title{
3. Methodology
}

Population is an overall aspect of a group of elements that has common characteristics and consists several areas to scrutinize. This study population consisted of 1220 students from public and private universities who have involved in Enactus (www.enactus.org). However, the researcher only focuses and selected 15 public universities across Malaysia that participating in Enactus. The proportionate sampling was utilized in this study. With proportionate stratification sampling, the sample size of every stratum is proportionate to the population size of the stratum. This suggests that every stratum has an equivalent sampling fraction of proportionate sampling. The population of this research will be measures proportionately in order to determine the number of respondents (Ranjit, 2011). Thus, the sample size for this study is 300 students.

A set of questionnaires that was adapted and adopted from Carrahar (2013) and Hockert (2015) was utilized to collect the data. The questionnaire was distributed to selected respondents using Google Form. This method can also help the researcher obtain data in a short time and low cost.Before the questionnaire was distributed, the researcher also conducted a pilot study to test the reliability and validity of the questionnaire. All required information and data were analyzed using the Special Package for Social Science Software (SPSS) using Windows version 23

In this study, data were analyzed using descriptive method consisting of mean and standard deviationto identify the level of student motivations' in social entrepreneurship and empathy among respondents. The Pearson correlation and simple linear regression in conducted to test the effect of empathy on students 'motivation in social entrepreneurship.

Image 8. The Effect of Empathy on Students' Motivation in Social Entrepreneurship among Undergraduates

Article 3: Factors Affecting Students Academic Performance

The method part of this article is not well developed and consistent.

\section{Factors Affecting Students Academic Performance}

\author{
Mohanraj $^{\mathrm{a}}$, Parul Vats ${ }^{\mathrm{b}}$, Swathi Rapetic, and Megha Sharma ${ }^{\mathrm{d}}$ \\ Assistant Professor (CSE), SRMIST, DELHI-NCR Campus, Modinagar \\ b,c,d M.Tech Student (CSE), SRMIST,DELHI-NCR Campus, Modinagar
}

Article History: Received: 10 January 2021; Revised: 12 February 2021; Accepted: 27 March 2021; Published online: 16 April 2021

\begin{abstract}
Many studies are carried out to find out the factors affecting students' performance Students' academic performance is impacted by many factors. Many factors may have an effect on student performance. To draw inference about whether factors like gender of the student, the race/ethnicity of the student, the level of education of their parents, the type of lunch they ate and whether the test preparation course has any impact on the scores obtained by the student in the tests.
\end{abstract}

Keywords: EDA, Random forest, Decision Tree, Logistic Regression. 
Article 4: e-Commerce-Leaders and Customers

All the in-text citation and reference are wrong in the selected article

Turkish Journal of Computer and Mathematics Education

Vol.12 No.6 (2021), 1445-1450

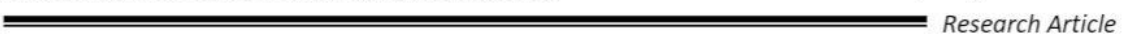

\title{
e-Commerce - Leaders and Customers
}

\author{
Dr. Abdulah M. Aseri \\ Department of Management Information Systems, College of Business Administration \\ Imam Abdulrahman Bin Faisal University, Saudi Arabia
} amaseri@iau.edu.sa

Article History: Received: 10 November 2020; Revised 12 January 2021; Accepted: 27 January 2021; Published online: 5 April 2021

\begin{abstract}
e-Commerce like the technology it is representative changes every day across the global marketplace. In fact, to keep abreast of hot topics and trends from a business perspective, savvy e-Commerce businesses specifically keep watch for what is prodding those surfing and searching the Internet to jump at sales within their own industries. The following provides both a birds-eye view and an insider lens to who are the leaders and customers of e-Commerce today, and why. The following also specifically discusses the tremendous impact Amazon continues to have setting standards for best practices in eCommerce. Other topics covered give insights on the demographics of who uses e-Commerce the most, and how Mobile-Commerce cannot be ignored to assure getting or maintaining a fair market share.
\end{abstract}

\section{Image 10. E-Commerce-Leaders and Customers}

Sluis reports how e-Commerce retailers see the situation as vital and the importance of getting mobile to work. It is a matter of having necessity to the point without m-commerce there will not be "much of an e-Commerce business in a year's time (Sluis 15)". At present, the desktop traffic is in the minority, and it continues to shrink (Sluis 15)". Sluis reports one forecast sees " 24 percent of its traffic from mobile phones, 23 percent from tablets, and the remaining 43 percent from desktops (15)" making up sales at "Schuch, a shoe retailer in the United Kingdom owned by Genesco (Sluis 15)".

While studies show fewer consumer visits via mobile devices resulting in sales, nonetheless, other valuable services come from mobile devices in the form of micro conversions at Web sites. Reviews by visitors immediately after visiting specific online stores proves desirable when others see it using a store locator (Sluis 15). "With numbers of retailers starting out with their own separate mobile sites the new trend shows moving to having responsive designs that allows adjusting to the users' screen size. "Fifty-three percent of retailers listed mobile optimization or responsive design as a top priority for 2014, making it the most popular area of focus (Sluis 15)".

\section{References}

[1]. Gold, Susannah. "PayPal Expands Reach with IZettle Acquisition." Global Finance June 2018: 67. https://www.questia.com/read/1P4-2070921421/paypal-expands-reach-with-izettleacquisition 18 Oct. 2018.

[2]. Goldenberg, Barton. "The E-Commerce Effect: This Key Pillar of Social CRM Is Changing the Business Landscape." CRM Magazine Oct. 2012: 4. https://www.questia.com/read/1G1304173417/the-e-Commerce-effect-this-key-pillar-of-social-crm 18 Oct. 2018.

[3]. Minsker, Maria. "More E-Commerce Experiences Are in Store: New Technology Enables Retailers to Bridge the Physical and Digital Divide for the Holiday Shopping Season." CRM Magazine Nov. 2014: 16. https://www.questia.com/read/1G1-388663201/more-e-Commerceexperiences-are-in-store-new-technology 18 Oct. 2018.

[4]. "PayPal Leads the Way in E-Commerce's Digital Cash Movement." THE JOURNAL RECORD 30 Oct. 2000. https://www.questia.com/read/1P2-5744522/paypal-leads-the-way-in-e-

\section{Image 11. E-Commerce-Leaders and Customers}


Article 5: Impact of Lockdown in the FMCG sector of the Indian Stock Market -Analysis using Statistical Methods In-text citation and reference are inconsistent in this article.

Turkish Journal of Computer and Mathematics Education $\quad$ Vol.12 No.1S (2021), $647-654$
Research Article
Impact of Lockdown in the FMCG sector of the Indian Stock Market - Analysis using
Statistical Methods
M. Vivek Prabu', R. Karthika ${ }^{2}$
1. Assistant Professor of Mathematics, ${ }^{2}$. M. Sc., Mathematics,
Kongunadu Arts and Science College (Autonomous), Coimbatore -641 029. India
Article History: Received:11 January $2021 ;$ Accepted: 27 February $2021 ;$ Published online: 5 April 2021
Abstract: The Covid19 outbreak has shattered the Global economy and Indian economy too had got no
exemption from it. Despite the GDP of India moving in the negative trend, very few sectors like Pharmaceutical
and FMCG have shown some positive signs because of this pandemic and the lockdown followed by it.
Consumer staples will always remain essential irrespective of the economical movement. In particular, during
the tougher times, whenever there arises an unprecedented scenario, the humankind will always try to safeguard
itself and in turn that will certainly cause a high demand in the FMCG sector. In this paper, we will be analysing
the impact of lockdown in the movement of the FMCG sector using some of the Statistical tools.
Keywords: GDP, NSE, Nifty 50 , FMCG Sector, Stock Analysis, Covid19, Lockdown, Pandemic, Statistical
Methods

Image 12. Impact of Lockdown in the FMCG sector of the Indian Stock Market -Analysis using Statistical Methods

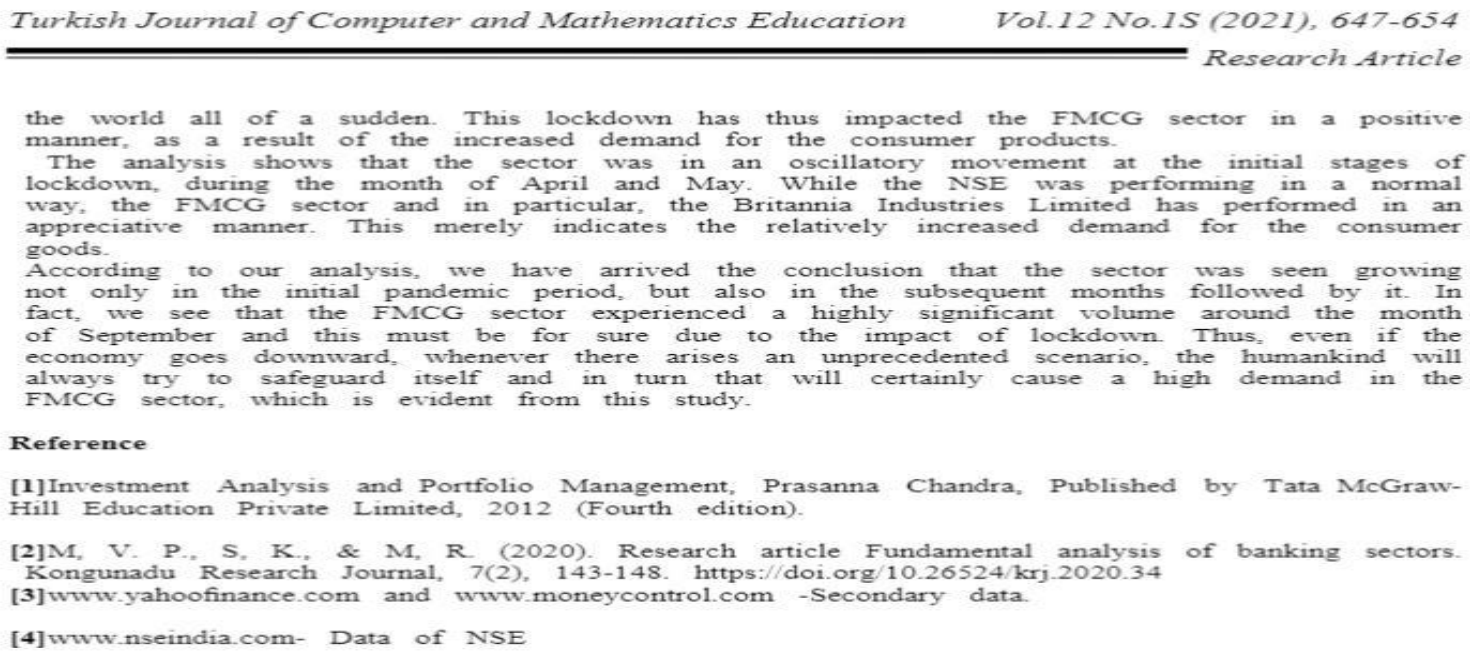

Image 13. Impact of Lockdown in the FMCG sector of the Indian Stock Market -Analysis using Statistical Methods

Article 6: The Impact of Corona-Virus Pandemic Effected the Air Pollution in India The name of all the graphs/diagrams is missing in the article. 


\author{
The Impact of Corona-Virus Pandemic Effected the Air Pollution in India \\ Shubham Chugh ${ }^{\text {a }}$, Ravi Kaushal ${ }^{\mathrm{b}}$, and Sahil Kohli ${ }^{\mathrm{c}}$ \\ University School of Business-Industry Collaborated Program, Chandigarh University, Mohali, Punjab
}

Article History: Received: 11 January 2021; Accepted: 27 February 2021; Published online: 5 April 2021

\begin{abstract}
In a country like India, where the major decease are been caused because of the Air pollution, which has affected around 4 million lives because of this pollution only, the cause of the rise in Air pollution is not only from the factories but also the vehicles which use to run on the streets as corona-virus can stay in the air for around 30 minutes, which can cause problems to millions of lives moving on the street, mostly the poor. In India air pollution has rated to almost least in the past 20 years which has contributed to the break from spreading. In India, Delhi and other most populated states stated a drastic downfall in Air pollution with about 60 percent decline in air pollution of PM - 2.5 particularly known as "fine particulate matters" in Delhi when compared with 2019 while the pollution control in other countries couldn't see much change and which has also seen a rise in corona-virus cases. In this paper we have analyzed the impact of rising in the number of the corona-virus cases concerning the most polluted cities to state the actual scenario that is air pollution leads to a rise in a pandemic situation. This paper is primarily based on secondary sources of data collection including the state-wise downfall in the level of air pollution, impact on the environment from the deadly disease i.e. Corona-virus, prospects, impact on the health of the individual.
\end{abstract}

Image 14. The Impact of Corona-Virus Pandemic Effected the Air Pollution in India

The researcher has randomly selected some articles of the selected journal for review. Article 16 are the title of the reviewed articles. There have many mistakes in the published articles. For example, objectives are inconsistent with data analysis and research framework, the methodology is wrongly presented, the in-text citation is wrong, references are absent in the bibliography part, and so on. Normally the predatory journals publish articles without the reviewing process.

Since Turkish Journal of Computer and Mathematics Education is Scopus indexed which has been confirmed by Scopus (Image 1), therefore, the researcher had sent two articles for publication to the journal. To know the reasons for thousand mistakes in the articles of the selected journal, there was no option except publishing articles in the journal.

There are a lot of dealers in social media who are engaged with this journal and the researcher took the help of two of them for publishing his papers.

\title{
Stages of Article Submission and Publication in Turkish Journal of Computer and Mathematics Education
}

\section{FIRST DEALER}




\section{Article submission}

Dalowar Hossan <upm.dalowarhossan.bd@gmail.com>

Fri, Apr 16, 2021 at 1:02 PM

To: testinghub.researcher@gmail.com

Dear Ms

I would like to publish this article in the Turkish Journal of Computer and Mathematics Education (TURCOMAT)

Thank you very much

Sincerely

Dalowar

四 $37 \mathrm{~K}$

docx

Image 15. Article submission to the first dealer 


\section{Turkish Journal of Computer and Mathematics Education (TURCOMAT)}

\section{ARTICLE ACCEPTANCE LETTER}

Date: $18 /$ March/2021

Dear Author,

Thank you very much for your submission to our journal.

We are pleased to inform you that your paper has been reviewed, and accepted for publication in Regular Issue of the journal based on the Recommendation of the Editorial Board without any major corrections in the content submitted by the researcher. This letter is the official confirmation of acceptance of your research paper.

Title: :

Author's:

Your research work is licensed under a Creative Commons Attribution 4.0 (International) License. (CC BY-NC 4.0). Hence no need to submit the Copyright form.

Kindly acknowledge the Paper acceptance. Thanks and looking to receive the payment from your side at the earliest

Best wishes,

Praf. Or. Aduan Baki

Editor in Chief

Trabzon Universitesi

Fatih Egitim Fakultesi

61300

Image 16. Back-dated acceptance letter received from first dealer 


\section{Article submission}

Testing Hub stestinghub.researcher@gmail.com>

To: Dalowar Hossan «upm.dalowarhossan.bd@gmail.com>

Dear Author,

Congratulations! Your paper has been accepted

Please find attached the acceptance letter

The processing charges for your manuscript will be $\$ 300$. ( $6 \%$ will be the extra Paypal fees, if paying by paypal)

You can transfer charges by Swift Transfer (Account details are mentioned at the end of the email for swift transfer.) Also, please make sure that the transfer charge should be completely taken care of by you.

Click on Pay now for Paypal transaction $\mathrm{P}$ a

(Note:- $6 \%$ will be the extra Paypal fees, if paying by paypal)

Please intimate after submitting your processing charges.

A scanned copy of the bank challan is required.

See below Account details for online trf :

\begin{tabular}{|c|c|}
\hline A/c Holder & Testing hub \\
\hline A/c. No & 6595002100004015 (Current Account) \\
\hline Bank Name & Punjab National Bank \\
\hline Branch & Sadhna nagar, Indore, Madhya Pradesh, India \\
\hline IF SC Code & PUNB0659500 \\
\hline Swift Code & PUNBINBB \\
\hline Location & $\begin{array}{l}\text { City : Indore } \\
\text { District : Indore } \\
\text { State : Madhya Pradesh } \\
\text { Country: India }\end{array}$ \\
\hline
\end{tabular}

Let me know in case of any query

Regards,

Charmee Shah

$+91-9039387535$

inimied tent Wawant 


\section{Article submission}

Testing Hub <testinghub.researcher@gmail.com>

Wed, Apr 21, 2021 at 7:19 AM

To: Dalowar Hossan <upm.dalowarhossan.bd@gmail.com>

https://turcomat.org/index.php/turkbilmat/arti

Your paper has been published

[Quoted text hidden]

Image 18. Publication confirmation mail from the first dealer

- turcomat.org/index.php/turkbilmat/issue/view/41

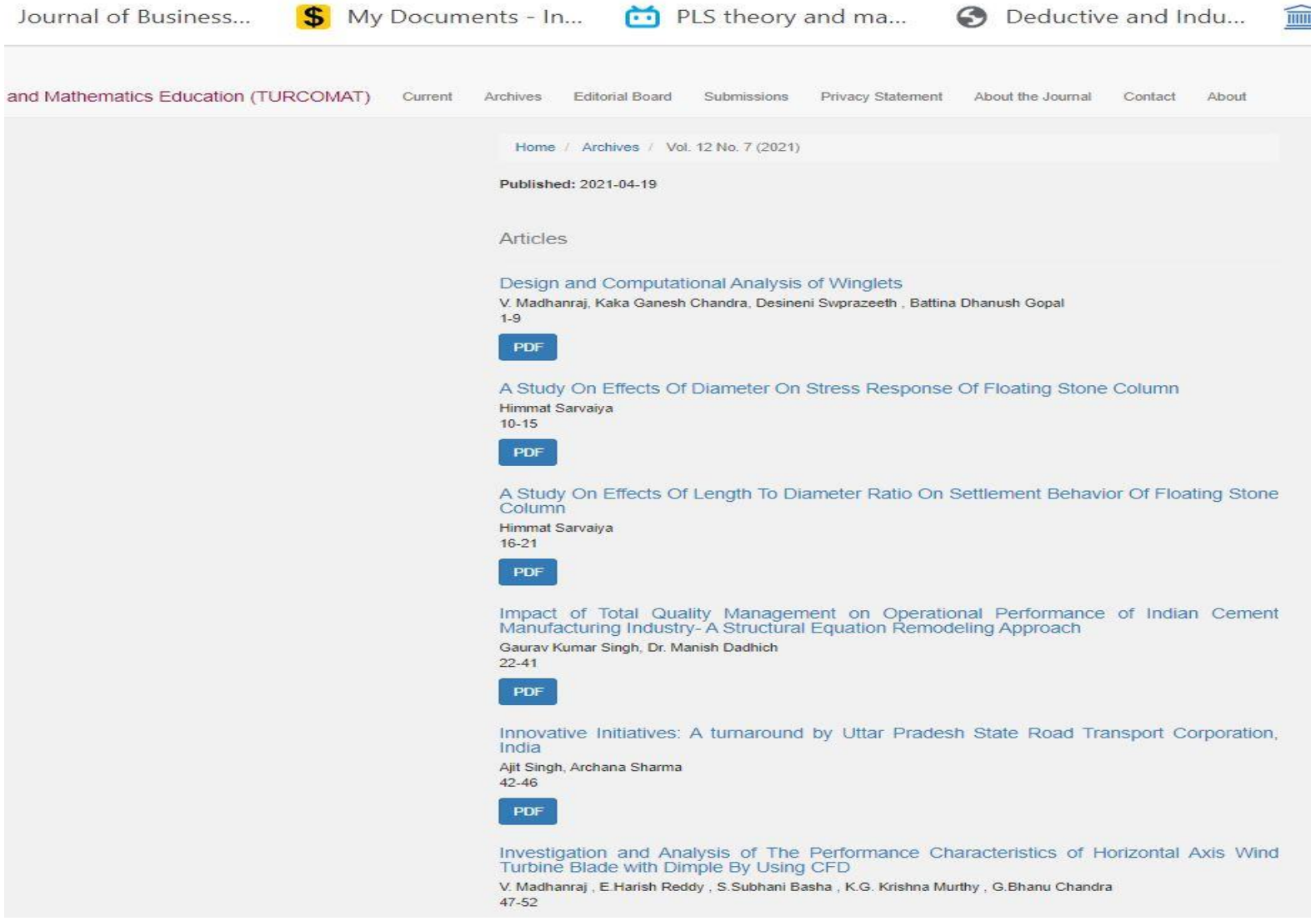

Image 19. Publication volume 12 No. 7 (2021) 
- turcomat.org/index.php/turkbilmat/issue/view/41

R Journal of Business..

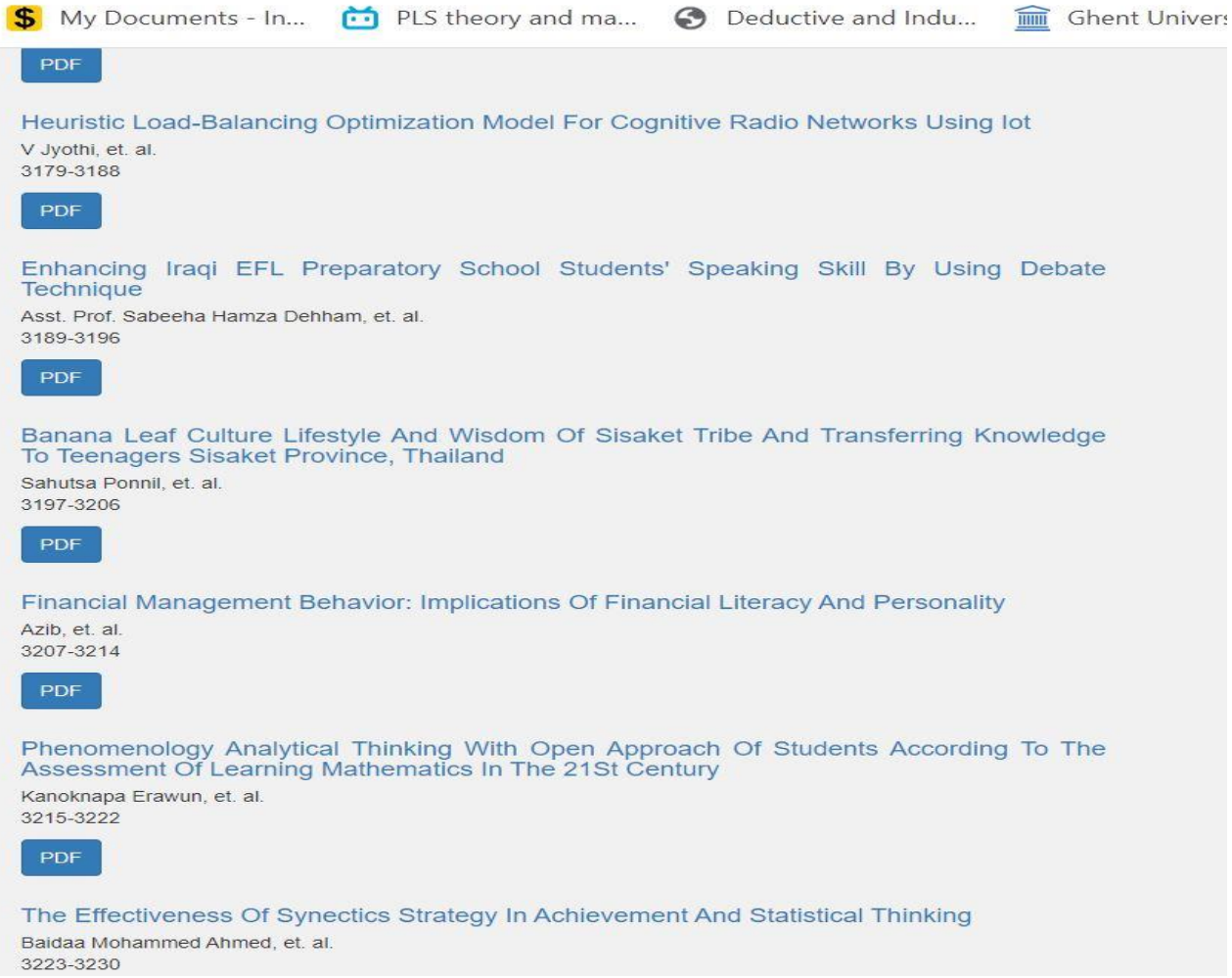

Image 20. Published Article in the journal

\section{SECOND DEALER}

\section{A Proposed. industry}

Dalowar Hossan <upm.dalowarhossan.bd@gmail.com> To: myresearchpublication03@gmail.com

\section{0 april article.docx}

$157 \mathrm{~K}$

Image 21. Article submission to the second dealer for publication in Turkish Journal of Computer and Mathematics Education 


\section{Notification for paper_P571}

research publication <myresearchpublication03@gmail.com>

To: Dalowar Hossan <upm.dalowarhossan.bd@gmail.com>

Tue, Apr 20, 2021 at 8:07 PM

Dear Corresponding Author,

Paper ID: Turcomat_2021_TUR_P571

Paper Title: A Proposed ..

industry

We are pleased to inform you that your research paper has been accepted for publication in Turkish Journal of Computer and Mathematics Education (TURCOMAT) in Current Issue of 2021.

The blind peer review process results are given below

Review Decision

1. Originality: $70 \%$

2. Article scope: $88 \%$

3. Understandable: Yes

4. References: Cited Properly

5. Result: Satisfactory

1. Originality: $85 \%$

2. Article scope: $79 \%$

3. Understandable: Yes

4. References: Cited Properly

5. Result: Satisfactory

Final Decision: Accepted

For any further query feel free to contact us.

Regards

Editorial Team

Turkish Journal of Computer and Mathematics Education (TURCOMAT)

www.turcomat.org

7 Acceptance Letter.pdf

$67 \mathrm{~K}$

Image 22. Acceptance letter from second dealer 
Re: Request for info about Turkish Journal of Computer and Mathematics Education ISSN 13094653 [210421-013632]

Scopus Support (ELS) <ScopusSupport@elsevier.com>

Thu, Apr 22, 2021 at 4:13 AM

Reply-To: "Scopus Support (ELS)" < ScopusSupport@elsevier.com>

To: dalowarhossan.bd@gmail.com

Dear Dalowar,

Thank you for contacting Scopus.

Regarding the journal entitled : Turkish Journal of Computer and Mathematics Education, I can confirm that the journal is active and currently scopus indexed (2021).

If I can be of any further assistance, please do not hesitate to contact me.

Kind Regards,

Mahalakshmi's.

Content Service Desk

ELSEVIER

Image 23. Scopus confirmation mail

\section{DISCUSSION}

Generally the journal uses https://turcomat.org/index.php/turkbilmat domain to publish articles and they publish a lot of articles. For example, Vol. 12 No. $1 \mathrm{~S}$ (2021); Vol. 12 No. 2 (2021); Vol. 12 No. 3 (2021); Vol. 12 No. 4 (2021); Vol. 12 No. 5 (2021); Vol. 12 No. 6 (2021); Vol. 12 No. 7 (2021). Most of the No. contains more than 400 articles.

According to the journal policy, it publishes three (3) issues in a year under https://dergipark.org.tr/en/pub/turkbilmat domain (see Image 4). But they publish lot of articles under https://turcomat.org/index.php/turkbilmat domain (refer to Image 3). It may be their business policy. Since the published articles have a lot of mistakes under https://turcomat.org/index.php/turkbilmat domain and the journal authority has declared that it is their new domain (Image 4), therefore it is revealed that the journal is trying to make money by doing predatory activities. They may change the announcement (which is available in image 2 and image 4) anytime to keep the journal in Scopus indexed.

Image 15 and Image 21 define the article submitted to the dealer of the journals on 16 April 2021 and 20 April 2021 respectively. On April 19, 2021, the researcher received an acceptance letter that was issued on a back date (see Image 16 and Image 17). The researcher received another acceptance mail on the submission date (20 April 2021) from the second dealer (refer to Image 22). That's means, the researcher received the first acceptance letter and second acceptance letter from the first dealer and second dealer within 3 days, and 7 hours, respectively. Image 18 stated the confirmation mail of the journal publication on April 21, 2021. Within 5 days the article had been published on the journal website. The researcher sent mail to the Scopus authority to know the current status of the selected journals (refer to Image 23) and it was under Scopus indexed at that time. The finding of the study is similar to the previous study of Hossan (2020). 
Based on the characteristics of the selected journal, we can state the following features of a predatory journal.

a. Accepting the articles very quickly, usually without independent criticism or quality control even articles with irrational content.

b. Rapid publication (no correction, direct publication; accepted within 7-10 days and published 30-45 days).

c. Only notify the author of the Article Processing Charge (APC) after the paper has been accepted or APC is unclear or APC can be negotiated after acceptance.

d. Actively sending unsolicited or bulk spam emails to invite to submit articles in upcoming issues or special issues or participate in the editorial board or reviewer of journals.

e. Bringing scholars to the editorial board without permission, and not letting them leave the editorial board.

f. Unqualified international scholars to the editorial board (lacking ORCID ID and/ fake research ID).

g. Use a name or website design that closely resembles prestigious journals;

h. Fake impact factor or databases, or not available.

i. There are unclear procedures for handling manuscripts and workflows of journals.

j. The website demands that papers must be sent via a private email.

$\mathrm{k}$. There is no withdrawn and retraction policy.

l. Information about where and how articles will be digitally conserved is absent.

m. Fraudulent placement of the Committee on Publication Ethics (COPE) logo on the journal website without really being a member of COPE.

n. "International Standard Serial Number" (ISSN) of one OA journal cannot be checked in DOAJ and/or ROAD.

o. Falsely claiming indexing in various reputed databases like PubMed, Pubmed Central, Medline, SCOPUS, and/or Web of Science

p. The articles of these journals contain faults in grammar and spelling, data analysis, result discussion. Images and logos are unprofessional, distorted, and fuzzy.

\section{CONCLUSION}

The prevailing scholarly ethos of "publish or perish" and the OA model cooperatively contributed to the present state of affairs. Prior to new submission, researchers can decide to submit their papers not only on the basis of checking 'black lists,' but also through carefully evaluating the characteristics of journals' DOAJ, ROAD, COPE, and ICMJE registries, and indexing reputable databases such as Scopus through their official websites. To avoid potential predatory journals, researchers should take into consideration some aforementioned suggested features of predatory journals. In a word, both readers and authors should fully boycott fake journals.

\section{ACKNOWLEDGMENT}

The Author has followed the terms of the Creative Commons Attribution Non-Commercial License (http://creativecommons.org/licenses/by-nc/4.0/). 


\section{DISCLAIMERS}

The materials and information in the article are presented for educational purposes only and the author has no intention to hurt people's feelings as well as their reputation.

\section{REFERENCES}

- Beall, J. (2016). Ban predators from the scientific record. Nature, 534(7607), 326-326.

- Beall's List of Predatory Journals and Publishers, https://beallslist.weebly.com/standalonejournals.html\#, last accessed 2019/12/10.

- Demir, S. B. (2018). Predatory journals: Who publishes in them and why?. Journal of Informetrics, 12(4), 1296-1311.

- Duc, N. M., Huy, H. Q., Keserci, B., \& Thong, P. M. (2020). A Preliminary Vietnamese Comparative Study of Postgraduate Radiological Thesis Characteristics. Medical Archives, 74(1), 42-46.

- Duc, N. M., Ha, H. D., Khoa, M. T., \& Thong, P. M. (2020). Impacts of Novel Vietnamese Government Regulations on Radiological PhD and Professorship Candidates: an Initial Report. Acta Informatica Medica, 28(2), 152-156.

- Duc, N. M., Thong, P. M., \& Masic, I. (2020). Predatory Open Access Journals are Indexing in Reputable Databases: a Revisiting Issue or an Unsolved Problem. Medical archives, 74(4), $\quad 323-326$

- Frandsen, T. F. (2017). Are predatory journals undermining the credibility of science? A bibliometric analysis of citers. Scientometrics, 113(3), 1513-1528.

- Hossan, D. (2020). Predatory journals are indexing in reputed databases: a case study of unsolved issues. International Journal of Social Science Research, 2(3), 126-143.

- Hu, D., Huang, B., \& Zhou, W. (2012). Open access journals in China: The current situation and development strategies. Serials Review, 38(2), 86-92.

- Macháček M. and Srholec M. (2019). Predatory Publications in Scopus: Evidence on Cross Country Differences. IES Working Papers 20/2019. IES FSV. Charles University.

- Masic, I. (2017). Predatory publishing-experience with OMICS International. Medica Archives, 71 (5), 304-307.

- Masic, I. (2016). Peer review-essential for article and journal scientific assessment and validity. Medical Archives, 70(3), 168-171.

- Masic, I. (2020). Unethical Behaviors of Authors Who Published Papers in the Biomedical Journals Became a Global Problem. Medical Archives, 74(1), 4-7.

- Nature Index 2018 reviews China's scientific performance over the past five years, https://group.springernature.com/fr/group/media/press-releases/nature-index-2018reviews-china-s-scientific-performance/16338530, last accessed 2019/9/4. 
- Scopus. (2018). Scopus on-line database. https://www.scopus.com, available in Macháček, V.\&Srholec, M. (2021). Predatory publishing in Scopus: evidence on crosscountry differences. Scientometrics 126, 1897-1921.

- Shen, C., \& Björk, B. C. (2015). 'Predatory'open access: a longitudinal study of article volumes and market characteristics. BMC medicine, 13(1), 1-15.

- Shuva, N. Z., \& Taisir, R. (2016). Faculty members' perceptions and use of open access journals: Bangladesh perspective. IFLA journal, 42(1), 36-48.

- Simón, A. (2016). Pitfalls of predatory journals: A personal account. Comprehensive Psychology, 5, 2165222816631691.

- Truth, F. (2012). Pay Big to Publish Fast: Academic Journal Rackets. Journal for Critical Education Policy Studies (JCEPS), 10(2).

- Xia, J., Harmon, J. L., Connolly, K. G., Donnelly, R. M., Anderson, M. R., \& Howard, H. A. (2015). Who publishes in "predatory" journals? Journal of the Association for Information Science and Technology, 66(7), 1406-1417.

- Xia, J. (2018). Applying Rational Choice Theory to Authors' Behaviors in Unethical Publishing in China. Library Trends, 67(2), 241-254. 